\title{
PELAMINAN ADAT MASYARAKAT MINANGKABAU (KAJIAN BENTUK DAN FUNGSI)
}

\author{
Nofi Rahmanita dan Yulimarni *)
}

\begin{abstract}
Aisle as a form of decorative artwork has particular unique and characteristics, contains the values associated with the livelihood of Minangkabau society. Its ppresence is very important for the sustainability of Minangkabau society cultural values preservation. Therefore, it should be revisited, how the structure and function of the aisle and how the changes shape and function of the aisle today.

The visual form of aisle has been less or more affected by current development. It happens solely to fulfill the aesthetic needs of community support, like the proverbial Minang said, "condong salero ka nan lamak, condong mato ka nan rancak" the taste prefer to the delicious one, the eye sight prefer to the beautiful one. This effect can be seen from the use of materials and techniques used for wedding decoration.
\end{abstract}

Kata Kunci: Form, Structure, Aisle.

\section{ABSTRAKSI}

Penelitian ini mempunyai tujuan untuk mencari tahu mengenai usaha Batik Topo, terutama produk kain batik yang dihasilkannya. Produk kain batik yang dihasilkan meliputi motif dan proses pembuatannya. Bagaimana motif-motif batik yang dibuat oleh Batik Topo. Apa dan bagaimana proses pembuatan kain-kain batiknya selama ini. Tujuan penelitian ini sangatlah jelas untuk mengetahui lebih mendalam dan terperinci mengenai segala hal yang diproduksi oleh Batik Topo, dalam hal ini kaitannya dengan produk kain batiknya.

Penelitian mengenai usaha Batik Topo ini tentunya membutuhkan metode penelitian. Metode penelitian untuk memecahkan permasalahan dalam penelitian menggunakan beberapa metode dari disiplin ilmu yang berbeda. Penelitian ini menggunakan metode multidisiplin. Beberapa metode dari disiplin ilmu yang berbeda di antaranya, yaitu: estetika; sejarah; dan antropologi. Sedangkan metode pencarian data dilakukan dengan cara, yaitu: observasi; wawancara; dokumentasi; dan pustaka.

Penelitian ini menghasilkan kesimpulan bahwa usaha Batik Topo membuat kain batik dengan cara cap dan tulis, sehingga produknya disebut batik cap dan tulis. Pembuatan kain batik dengan cara demikian ikut mendukung pelestarian batik tradisional. Kain batik tradisional

\footnotetext{
* Nofi Rahmanita dan Yulimarni (nofi.tekstil@gmail.com), Staf Pengajar Program Studi Kriya Seni, Jurusan Kriya, Fakultas Seni Rupadan Desain, Institut Seni Indonesia Padangpanjang
} 
dengan pembuatan secara cap maupun ditulis menggunakan canting telah diakui sebagai world heritage.

Keywords: batik topo, batik, batik cap, batik tulis, world heritage.

\section{PENDAHULUAN}

Upacara perkawinan sebagai aktivitas budaya, merupakan peresmian hubungan antara seorang laki-laki dengan seorang perempuan dari suatu kaum untuk memasuki dunia dewasa. Tidak hanya itu, upacara perkawinan juga menjadi upacara penyatuan dua kaum yang berbeda latar belakang, kedudukan dan lain sebagainya. Dalam konteks ini pelaminan memiliki peranan yang sangat penting. Sebagaimana diketahui bahwa pelaminan merupakan salah satu presentasi dari kemegahan dan kemampuan dari masing-masing kaum. Dalam ketentuan adat sebelumnya pelaminan hanya boleh dipakai oleh orang-orang tertentu saja, harus jelas statusnya apakah keluarga penghulu atau keluarga raja, jika tidak ia harus meminta izin terlebih dahulu dengan membayar atau mengisi uang adat sebagai persyaratan sesuai dengan ketentuan adat di masing-masing daerah. Sesuai pepatah yang mengatakan lain lubuak lain ikan, lain padang lain ilalang.

Setiap rumah bangsawan, datuk, dan orang basa (besar) Luhak, mempunyai dan akan memasang pelaminan di rumah mereka yang beratap gonjong. Begitu juga dengan daerah rantau yang rumah adatnya dikenal dengan rumah bakolam, atau disebut juga rumah rantau. Berdasarkan hal itu pula tergambar bahwa di Minangkabau dulunya terdapat strata sosial, maka dikenal tingkatan perhelatan sesuai kebangsawanan mereka.

Seiring dengan berjalannya waktu terjadi perubahan, dimana pelaminan sudah menjadi barang sewaan dan dipakai dalam setiap acara perhelatan tanpa memandang status, asalkan masyarakat tersebut mampu membayar sesuai dengan aturan yang sudah ditentukan. Pelaminan berfungsi sebagai tempat duduk anak daro dalam menunggu kedatangan marapulai untuk dipersandiangkan, setelah ijab kabul. Kedatangan marapulai ke rumah anak daro merupakan lambang atau representasi dari sistem perkawinan matrilokal (laki-laki datang kerumah perempuan) dalam konstelasi adat Minangkabau yang matrilineal. (Puti Reno, 2009:9).

Pelaminan sebagai tempat bersanding kedua penganten menyerupai singgasana raja. Sehubungan dengan hal itu anak daro dan marapulai diibaratkan sebagai raja dan ratu sehari yang duduk 
disinggasana. Pelaminan terbentuk dari susunan elemen seni rupa dan dihiasi dengan ragam hias. Unsur yang terdapat pada pelaminan bukan hanya sekedar untuk memenuhi rasa keindahan semata, akan tetapi merupakan simbolsimbol yang mencerminkan kehidupan sosial masyarakat Minangkabau. Di balik keindahannya tersimpan nilai-nilai sejarah dan makna yang dalam. (Sri Sundari, 2004:32)

Pelaminan sebagai salah satu bentuk hasil karya seni dekoratif interior, dan setiap unsur pelaminan dipenuhi dengan hiasan yang diwujudkan dengan teknik sulaman. Keunikan dan karakteristiknya mengandung nilai-nilai yang komplek dan mendalam terkait erat dengan tatanan kehidupan masyarakat Minangkabau. Dengan begitu keberadaannya sangat penting bagi keberlangsungan pelestarian nilai-nilai budaya masyarakat Minangkabau.

Pada saat ini secara visual bentuk dan fungsi pelaminan serta ragam hias yang ditampilkan telah dikembangkan dengan berbagai macam kreasi dan modernisasi dalam penataan, namun tetap ada batas yang harus ditaati. Halhal penting yang bercirikan Minangkabau di palaminan harus tetap ada, seperti kain bersulam benang emas atau perak dengan ragam hias Minangkabau, banta gadang, langiklangik, di atas tempat bersanding bergantung mainan angkin dan Ialansia, kulambu, yang kesemuanya itu mengandung makna yang tersimpan dalam palaminan. Palaminan merupakan suatu warisan budaya yang terus bertahan sampai sekarang, dan memiliki suatu kesatuan struktur bentuk yang organis. Oleh sebab itu maka dibuatlah rumusan masalah dalam penelitian ini, yaitu: Bagaimana bentuk dan fungsi dari pelaminan yang dibuat oleh masyarakat Minangkabau, dan Bagaimana perubahan bentuk dan fungsi pelaminan Minangkabau yang saat ini sudah mengalami perubahan dan fungsinya sehingga jauh dari kaedah-kaedah dalam adat Minangkabau.

\section{PEMBAHASAN}

Pelaminan memegang peranan penting dalam upacara adat di Minangkabau. Pada hakekatnya pelaminan merupakan singgasana dalam sebuah istana khususnya di Minangkabau, yang terdiri dari beberapa komponen dengan bahan kain dan beragam warna yang ditata sedemikian rupa. (Anwar Ibrahim, 1984:86). Mulanya pelaminan digunakan sebagai tempat terhormat bagi para raja atau bangsawan Minangkabau, tetapi sekarang sudah banyak dipakai oleh masyarakat umum sebagai perangkat upacara perkawinan.

Pelaminan bagi masyarakat Minangkabau tidak hanya dapat dilihat sebagai suatu hiasan dekorasi semata, tetapi merupakan bagian yang sakral 
dalam sebuah upacara adat perkawinan. Pelaminan adalah sebagai tempat bersandingnya anak daro dan marapulai setelah terjadinya ijab kabul dan sekaligus sebagai tempat diresmikannya hubungan kedua mempelai secara adat yang disaksikan oleh ninik mamak dan seluruh kaum kerabat kedua belah pihak.

Terjadinya perubahan fungsi pelaminan tersebut, juga membawa pengaruh pada bentuk dan hiasan pelaminan itu sendiri. Perubahan terjadi karena perkembangan zaman yang dilaluinya. Pergantian generasi yang berbeda kondisi budaya masyarakatnya, dan juga lingkungan yang berbeda berimplikasi munculnya kebutuhan yang berbeda. Dalam hal ini Edi Sedyawati menjelaskan, bahwa perubahan kebutuhan hidup, perubahan nilai yang dianut, dan perubahan kepercayaan, memberi pengaruh pula pada perkembangan dan perubahan seni. (Edi Sedyawati, 1991:iv).

Pelaminan sebagai bentuk karya seni dekoratif yang keberadaannya tidak terlepas dari pengaruh sosialkultural masyarakat pendukungnya. Dalam proses pengungkapannya telah melahirkan proses baru, yang berorientasi pada kebutuhan masa kini, sehingga melahirkan bentuk-bentuk yang baru. Sebagai ungkapan kreativitas budaya masyarakat Minangkabau sejak dulunya, pelaminan telah memberi peluang pada masyarakat untuk bergerak memelihara, menularkan dan mengembangkan untuk kemudian menciptakan kebudayaan baru lagi. (Umar Kayam, 1981:52).

Secara visual pelaminan Minangkabau memiliki nilai estetik yang tinggi, hal ini sangat jelas tergambar dari komposisi dan kombinasi dari berbagai komponen yang saling mendukung satu dengan yang lainnya. Setiap komponennya memiliki bentuk yang variatif dan dihiasi dengan sulaman emas (lihat gambar 1 dan 2). Selain itu juga didukung dengan kombinasi warna yang memberikan kesan mewah dan elegan. Namun di balik itu semua pelaminan memiliki makna yang tersirat dari setiap strukturnya. Makna tersebut sangat terkait dengan nilai-nilai kehidupan masyarakat Minangkaau.

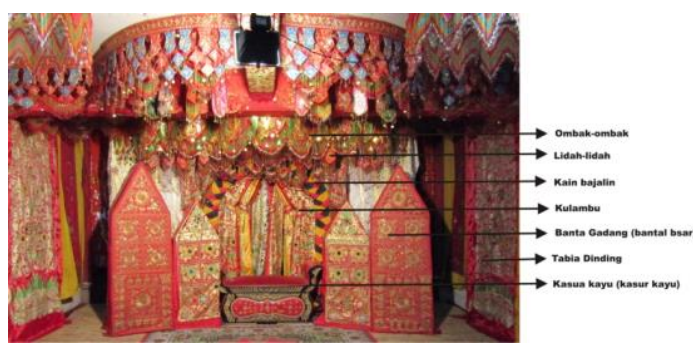

Gambar 1. Bentuk Pelaminan

Dokumentasi Pusat Dokumentasi Informasi Kebudayaan Minangkabau (PDIKM) Padangpanjang Foto: Yuli, Padangpanjang, 2016

\section{Struktur Bentuk Pelaminan}

Bila dilihat secara visual pelaminan merupakan pengorganisasian dari unsur-unsur seni rupa yang disusun dalam satu kesatuan karya seni. Djelantik menjelaskan, bahwa sebuah 
karya seni dapat dinikmati apabila mengandung dua unsur mendasar yaitu bentuk (from) dan struktur atau tatanan (structure). Bentuk dasar unsur seni rupa adalah titik, garis, bidang, ruang, dan warna. Struktur adalah cara menyusun dari unsur-unsur seni rupa tersebut, sehingga terjalin hubungan yang berarti di antara bagian-bagian dari keseluruhan perwujudan. (Djelantik, 2004:18).

Lebih lanjut Dharsono menjelaskan bahwa ada tiga komponen dalam proses cipta seni sebagai landasan berkarya. Ketiga komponen tersebut adalah subject matter (tema pokok), from (bentuk), dan content (isi atau makna). Subject matter merupakan rangsangan cipta seniman dalam usahanya untuk menciptakan bentuk-bentuk yang menyenangkan. Dalam sebuah karya seni hampir dapat dipastikan adanya subject matter, yaitu inti atau pokok persoalan yang dihasilkan sebagai akibat adanya objek. From atau bentuk totalitas dari pada karya seni. Bentuk merupakan organisasi atau satu kesatuan atau komposisi dari unsur-unsur pendukung karya. Content atau makna merupakan bentuk psikis dari seorang penghayat yang baik. Perbedaan bentuk dan makna hanya terletak pada diri penghayat. Bentuk psikis seorang seniman pencipta merupakan bentuk yang disebut subject matter, seniman penghayat adalah penghayat yang punya bentuk psikis yang dihasilkan dari proses hayati oleh dunia idenya dan hasil proses imajinasi atau kreativitas. (Dharsono, 2007:3132).

Terkait dengan pelaminan, sebagai bentuk totalitas dari karya seni masyarakat masa lampau merupakan satu kesatuan dari berbagai unsur seni rupa sehingga melahirkan bentuk karya seni deoratif. Secara tekstual pelaminan adalah pengorganisasian dari berbagai komponen, setiap komponennya terbuat dari bahan dasar kain dan dihiasi dengan ragam hias yang bersulamkan benang emas. Komponenkomponen tersebut adalah sebagai berikut:

a. Dasar pelaminan

Dasar pelaminan merupakan komponen pelaminan yang terletak di bagian belakang, melekat pada dinding atau berdiri sendiri dengan menggunakan kerangka dari kayu atau besi. Dasar pelaminan ini disebut juga dengan latar belakang pelaminan berfungsi untuk menutupi dinding bagian belakang pelaminan. Bahan yang digunakan adalah kain beludru polos atau kain satin polos (tidak bermotif) berwarna merah.

b. Kain bakabek (kain berikat)

Kain bakabek adalah kain beludru yang digantung tegak lurus di kiri kanan depan dasar pelaminan. Kain tersebut diikat longgar bagian tengahnya.

c. Kain balapiah (kain jalin)

Kain balapiah berfungsi sebagai pembatas kelambu, kain dijalin pada kerangka kayu atau besi dipasang tegak 
lurus pada sisi kiri dan kanan sebagai bingkai pelaminan. Kain balapiah terbuat dari kain satin atau beludru yang terdiri dari tiga warna yaitu merah, kuning, dan hitam untuk daerah darek dan merah, kuning, biru untuk wilayah pesisir. Bentuk kerangka kain jalinan ini juga memiliki perbedaan dari dua wilayah tersebut yaitu, di wilayah darek kain jalin dibuat tiga sisi: kiri, kanan dan atas sedangan di wilayah pesisir dibuat melengkung. Masing-masing kain jalin memiliki ukuran selebar $10 \mathrm{~cm}$ yang dijalin berselang seling dan tumpang tindih antara satu sama lainnya, sehingga menciptakan keserasian susunan yang harmonis. Sekarang ini disebagian daerah telah ada pula kain jalin yang hanya menggunakan satu warna yakni kain polos berwarna emas, hal ini terjadi karena tuntutan perkembangan zaman.

d. Sebeang atau lansie

Sebeang atau lansie adalah dua helai kain yang dipasang secara vertikal (tegak lurus dikiri kanan) terletak di depan kelambu sebagai pengikat kain bakabek. Sebeang berukuran $25 \mathrm{~cm} \mathrm{x}$ $200 \mathrm{~cm}$ dihiasi dengan ragam hias yang bersulamkan benang emas, dan dikombinasi dengan sulaman suji caia serta kapalo peniti. Ragam hias yang terdapat pada sebeang antara lain, burung merak, kaluak paku, dan motif bunga serta daun. Di atas sebeang terdapat kaniang sebeang yang berukuran $25 \mathrm{~cm} \times 25 \mathrm{~cm}$. Kaniang sebeang terletak di atas sebeang, dan menutupi sebagian badan sebeang, keduanya merupakan satu kesatuan.

e. Kalambu (kelambu)

Kalambu adalah kain yang digantungkan antara dua kain jalin, terdiri dari bagian kiri dan kanan, bila dikuakkan maka akan tampak seperti ada ruangan lain di belakang pelaminan. Kalambu dipasang secara berlapis dengan jumlah yang berbeda-beda, ada pelaminan yang memakai kalambu tiga, lima dan tujuh lapis tergantung pada tingkat orang yang melakukan perkawinan. Setiap lapisan ditata miring atau melebar keluar agar ketika kain kalambu diikat longgar bagian tengahnya maka setiap lapisan bagian belakang tetap akan kelihatan.

f. Tonggak katorok

Merupakan kain yang dibalutkan pada tiang dari kayu atau besi kemudian diikat menjadi beberapa bagian sehingga berbentuk bergelombang, tonggak katorok ini dipasang di sisi kiri dan kanan kain bajalin. Disebagian daerah tonggak katorok ini tidak lagi diperlihatkan.

g. Banta Gadang (bantal besar)

Secara visual banta gadang berbentuk bangunan kecil terbuat dari kerangka kayu atau besi, terdiri dari dua bagian badan berbentuk balok segi empat dan bagian atasnya berbentuk balok segi tiga. Kerangka banta gadang tersebut dibalut dengan kain satin warna merah atau kuning yang sudah disulam dengan benang emas. Motif sulam yang terdapat pada banta gadang 
antara lain, puti takuruang, ula garang, itiak pulang patang, pucuak rabuang, ombak-ombak, senggan, pitih-pitih, biku-biku, kaluak paku, saluak laka, dan pacah ampek banta gadang. Banta gadang ini biasanya berukuran $\pm 60 \mathrm{~cm}$ $\times 50 \mathrm{~cm} \times 120 \mathrm{~cm}$. Posisi banta gadang terletak sebelah kiri dan kanan bagian luar kain jalin, dan sekaligus sebagai pembatas pelaminan. Awalnya banta gadang berfungsi sebagai tempat menyimpan pakaian adat mempelai laki-laki sebelah kanan dan pakaian mempelai wanita di bagian kirinya, namun sekarang ini fungsi tersebut tidak terlihat lagi.

h. Banta Ketek (bantal kecil)

Banta ketek adalah bantal yang berukuran kecil berbentuk balok segi empat yang dibungkus dengan kain satin dan dihiasi dengan sulaman benang emas. Motif hias yang terdapat pada banta ketek, seperti kaluak paku, dan saik ajik. Banta ketek berjumlah 8 buah yang disusun 4 di kiri dan 4 di kanan di atas dan ada juga sebagian orang meletakkannya di belakang kasua kayu.

\section{i. Kasua kayu}

Komponen pelaminan ini terbuat dari kayu yang berukir dan diatasnya diberi alas berupa kasur yang dijadikan sebagai alas duduk dari kedua penganten. Kasua kayu ini umumnya berukuran $70 \times 40 \times 150 \mathrm{~cm}$.

j. Lidah-lidah dan angkin-angkin

Lidah-lidah dan angkin-angkin merupakan elemen yang dipasang melekat pada ondas (ombak-ombak). Lidah-lidah berbentuk seperti dasi atau lidah manusia, dengan warna dasar antara lain biru muda, merah muda, hijau dan hitam. Sedangkan angkinangkin secara umum berpola seperti sebuah kalung yang terbuat dari kain saten dan bagian atas dan bawahnya diisi dengan kapas sehingga terlihat lebih timbul. Kedua elemen tersebut terbuat dari bahan kain saten dan permukaannya diberi hiasan sulaman benang emas dan variasi hiasan api-api.

Lidah-lidah dan Angkin-angkin berfungsi sebagai aksesoris untuk menambah semarak dan keindahan pelaminan. Motif yang terdapat pada angkin-angkin hanya sebagai fungsi estetis dan tidak mengandung makna. Unsur angkin-angkin dalam bahasa adat disebut rimbun rambaian artinya bersemarak bagaikan rumah gadang.

\section{k. Tabia dindiang}

Tabia dindiang adalah kain penutup dinding bagian kiri dan kanan pelaminan dengan ukuran $275 \mathrm{~cm}$ x 125 $\mathrm{cm}$. Tabia ini berbentuk lembaran kain yang bersulaman benang emas. Bahan yang digunakan beragam seperti kain beludru, satin, dan silk palapa, sedangkan motif yang terdapat pada tabia dindiang memiliki fungsi estetis dan tidak mengandung makna. Tabia memiliki tiga macam warna yaitu biru, kuning, dan merah.

1. Tirai langik-langik/tirai kolam

Tirai langik-langik selain berfungsi sebagai hiasan juga berfungsi untuk 
menutupi bagian loteng atau langitlangi rumah. Tabia juga dipergunakan untuk menutup bagian lereng pintupintu kamar, dinding kiri dan kanan, sewaktu ada upacara adat atau perkawinan. Tirai langik-langik dihiasi dengan sulaman benang emas dengan ragam hias sebagai fungsi estetis dan tidak mengandung makna. Adapun warna dari tabia langik-langik adalah hitam, kuning, dan merah.

m. Tirai ombak

Tirai ombak atau ombak-ombak dipasang bagian pinggir atas dinding, sehingga menutupi bagian atas tirai tabia. Komponen palaminan ini dibuat di atas dasar kain beludru dan silk dengan warna dasar Minangkabau, yaitu merah, kuning, dan hitam. Komponen ini dihiasi dengan motif berbentuk bunga dan daun yang disulam dengan benang emas.

n. Dulamak

Dulamak berfungsi sebagai penutup tudung saji sekaligus dulang tinggi. Kedua komponen ini merupakan pelengkap pelaminan yang terletak terpisah yaitu di sisi sebelah kiri dan kanan depan pelaminan. Dulamak berasal dari kata "daun dan lamak", (Aswar, 1999: ...) oleh masyarakat Nareh Pariaman diartikan "di dalamnya lamak (enak). Dulamak terbuat dari kain beludru warna hitam dan merah yang diberi hiasan kaca dengan sulaman benang emas, pada bagian belakang dulamak dilapisi dengan kain saten warna merah.
Semua komponen-komponen tersebut saling melengkapi satu sama lainnya, sehingga menjadi satu kesatuan yang utuh yang disebut dengan pelaminan. Ragam hias yang melekat pada setiap komponen pelaminan merupakan penggambaran dari bentukbentuk yang ada di alam, diantaranya bentuk flora, fauna, dan alam benda lainnya. Hal ini sesuai dengan falsafah alam takambang jadi guru, yang bermakna alam sebagai sumber untuk ditiru, namun peniruan tersebut telah distilisasi, dengan kata lain bentukbentuk alam yang ada pada pelaminan tidak sepenuhnya menyalin bentuk asli dari alam akan tetapi telah mengalami penggubahan bentuk. Bila dilihat secara sepintas memang tidak begitu jelas bentuk apa yang digambarkan, seakanakan berbentuk sebuah relung yang indah, namun jika diamati dengan cermat maka akan terlihat jelas apa yang digambarkan. Hiasan yang melekat pada pelaminan tersebut selain bermanfaat lahiriah sebagai memperindah suatu benda, juga mengandung arti dan makna yang direalisasikan dalam kehidupan masyarakat Minangkabau.

\section{Fungsi Pelaminan}

Pelaminan sebagai produk budaya masyarakat Minangkabau memiliki nilai fungsional, sehingga faktor kegunaan dan faktor estetis suatu produk menjadi prioritas utama sebagai daya tarik. Karya seni yang memiliki nilai fungsional 
yang tepat dan berkualitas estetik yang memadai dapat membangkitkan minat serta selera si pemakai (Gustami, 2000: 181). Feldman menjelaskan bahwa fungsi-fungsi seni yang sudah berlangsung sejak zaman dahulu, adalah untuk memuaskan: 1) kebutuhankebutuhan individu kita tentang ekspresi pribadi, 2) kebutuhankebutuhan sosial kita untuk keperluan display, perayaan dan komunikasi, 3) kebutuhan-kebutuhan fisik mengenai barang-barang dan bangunan yang bermanfaat (Feldman, 1991:2).

Dalam pengertian yang lebih luas Felmand membagi fungsi seni menjadi tiga bagian, yaitu fungsi personal, fungsi sosial dan fungsi fisik.

a. Fungsi personal

Fungsi personal seni dalam kebutuhan individu adalah tentang ekspresi pribadi. Seni sebagai alat ekspresi seniman tidak hanya sebatas ilham saja, tidak semata-mata berhubungan dengan emosi dari seniman, tapi seni mengandung pandangan seniman tentang peristiwa dan objek umum dalam kehidupan dan situasi kemanusian yang mendasar.

Untuk mengekspresikan perasaan dan gagasannya, seseorang menggunakan bermacam-macam media dalam pengungkapannya. Seni kerajinan pelaminan sebagai bagian dari seni rupa, bagi perajin pelaminan adalah salah satu media tersebut. Perajin pelaminan sebagai pribadi, dalam memenuhi kebutuhan estetisnya berusaha menciptakan produk pelaminan seindah mungkin, menyenangkan apabila dipandang. Pembuatan pelaminan umumnya bersifat fungsional, menuntut dan membantu perajin di dalam memuaskan keinginan serta kebutuhan estetis orang yang akan memakai karya seni tersebut, di samping kepuasan estetis perajin itu sendiri.

b. Fungsi sosial

Feldman menjelaskan bahwa karya seni memiliki fungsi sosial, yaitu: 1). karya seni itu mencari atau cenderung mempengaruhi perilaku kolektif orang banyak, 2). karya seni itu diciptakan untuk dilihat atau dipakai, khususnya dalam situasi-situasi umum, 3). karya seni itu mengekspresikan atau menjelaskan aspek-aspek tentang eksistensi sosial atau masyarakat kolektif sebagai lawan dari bermacammacam pengalaman personal maupun individu.

Seni karajinan pelaminan yang dihasilkan oleh masyarakat Minangkabau memiliki fungsi sosial, karena karya seni yang dihasilkan untuk memenuhi kebutuhan konsumen atau masyarakat, khususnya untuk perlengkapan dalam upacara adat atau upacara perkawinan. Hal ini sesuai dengan yang dijelaskan oleh Felmand pada poin dua di atas, dimana karya seni diciptakan untuk dilihat atau dipakai khususnya dalam situasi-situasi umum. Fungsi sosial pelaminan pada upacara adat, disamping nilai estetis karya 
tersebut, juga karena corak tradisi dan unsur-unsur simbolik ragam hias yang ditampilkan.

c. Fungsi fisik

Fungsi fisik seni adalah suatu ciptaan objek kebendaan yang berfungsi sebagai wadah dan alat. Wadah dan alat perlu dibentuk dan didesain secara khusus yang disesuaikan dengan persyaratan yang dikehendaki. Produk seni kerajinan selain dipergunakan sekaligus juga dilihat, sehingga perlu didesain sebaik-baik mungkin. Untuk itu proses awal pembuatan karya seni perlu pertimbangan faktor estetiknya. Sentuhan estetik dalam karya seni akan berperan sebagai daya tarik penampilan karya yang dihasilkan.

Fungsi fisik pelaminan sebagi produk yang mempunyai nilai guna, dapat dilihat pada setiap upacara adat yang dilaksanakan oleh masyarakat Minangkabau pada umumnya. Dalam hal ini penggunaan produk pelaminan merupakan tuntutan adat, karena setiap struktur pelaminan terkandung nilai adat dengan segala falsafahnya.

Struktur pelaminan secara keseluruhan menyerupai gerbang istana, yang terdiri dari suatu pengorganisasian, penataan, dari elemen-elemen yang ada,(Djelantik, 41) Bentuk gerbang dalam dunia simbolik dikaitkan dengan perlambangan "pintu mistik", yang membatasi antara dunia profan dan dunia sakral. Di sini simbol pelaminan membawa tanda-tanda konvensional dari sebuah perkawinan.
Perkawinan merupakan suatu tahapan dalam kehidupan manusia yang membawa perubahan dalam hidup seseorang dalam bentuk status baru.

\section{Gaya Sulam Pelaminan}

Konsep gaya merupakan bagian yang tidak dapat dihindari dalam mengkaji seni, meskipun ia dapat menjadi sumber kerancuan, karena gaya memiliki begitu banyak makna yang berbeda. Kadangkala gaya menunjukkan sebuah karya pada satu periode sejarah khusus. Gaya dapat pula menunjukkan seni suatu daerah dalam suatu negeri. Pada tingkat yang paling luas dan umum, suatu gaya seni merupakan sebuah pengelompokkan atau klasifikasi karya seni. Feldman membagi gaya seni melalui waktu, daerah, ujud, teknik, subject matter (Feldman, 1967:1).

Lebih lanjut Soedarso,SP menjelaskan,bahwa dalam mengamati gaya,corak atau langgam ataupun style (stijl) sebuah karya seni, sebenarnya berurusan dengan bentuk luar sesuatu karya seni, sedangkan aliran, faham atau "isme" lebih menyangkut pandangan atau prinsip yanglebih dalam sifatnya. Maka dekoratif adalah gaya, karena istilah ini dipakai untuk menamai lukisan, misalnya yang bentuknya seperti dekorasi, ngarawit buatannya, dan kurang memperhatikan dimensi ketiga (Soedarso, SP, 1990:93).

Berdasarkan teori di atas, maka produk kerajinan sulam pelaminan 
masyarakat Minangkabau merupakan produk budaya tradisional, keberadaannya sudah ada sejak zaman dahulu. Proses perwujudannya diawali oleh keterampilan para perajin dengan teknik yang telah mereka kuasai sejak kecil, sehingga menghasilkan karya seni berkualitas baik. Kerajinan sulam pelaminan yang dihasilkan saat ini tidak lagi terikat dengan segala aturan pemakaian pelaminan, hal ini disebabkan oleh perkembangan zaman dimana orang lebih suka memakai bentuk baru dari pelaminan. Walaupun bentuk, gaya ataupun corak pelaminan yang dihasilkan banyak mengalami modifikasi, namun tidak boleh lepas dari ketentuan-ketentuan adat.

Sulam pelaminan dipenuhi dengan corak tradisional, bisa diamati dari bentuk ragam hias yang ditampilkan. Penerapan ragam hias tradisional Minangkabau pada setiap produk, tidak mengalami perubahan dengan ragam hias yang dipakai dalam pembuatan sulam pelaminan untuk perangkat ritual adat. Makna filosofis yang terkandung dalam berbagai bentuk ragam hias yang diterapkan sesuai dengan filosofi kehidupan masyarakat pendukungnya, ketika menciptakan ragam hias tersebut. Dalam menciptakan karya seni yang mengandung makna, akan dipengaruhi oleh zaman dan tempat atau daerah orang yang menciptakannya. Sumardjo menjelaskan bahwa karya seni yang baik akan mampu membangkitkan atau mempengaruhi sebahagian emosi masyarakat tertentu sesuai dengan zamannya (Jakob Sumardjo, 2000:127). Bahkan lebih jauh karya seni tersebut bisa melambangkan jati diri budaya bangsa yang mencerminkan pola pikir dan prilaku hidup masyarakat pada zamannya.

Ragam hias yang diterapkan pada pelaminan Minangkabau merupakan ragam hias tradisional yang bersifat turun temurun. Jenis dan bentuk ragam hias yang ditampilkan merupakan warisan yang diterima oleh perajin sulam pelaminan terdahulu. Bahkan menurut keterangan beberapa orang perajin, melalui pengamatan dari bentuk ragam hias, teknik sulam, dan proses menyulam benang emas pada motif yang diterapkan, akan dapat diketahui dari mana asal pelaminan tersebut, apakah dari daerah darek atau daerah rantau.

\section{PENUTUP}

Pelaminan merupakan pengorganisasi dari beberapa unsur yang tidak dapat dipisahkan. Di setiap unsur atau elemen-elemen yang terdapat pada pelaminan mempunyai nilai estetik dan makna yang dalam terkait dengan tatanan kehidupan masyarakat Minangkabau.

Perkembang zaman sedikit banyak telah mempengaruhi bentuk struktur pelaminan, seperti pepatah Minang mengatakan, "condong salero ka nan lamak, condong mato ka nan 
rancak". Perkembangan tersebut terlihat dari penggunaan bahan dan teknik hiasan yang digunakan. Secara visual peranan sulaman benang emas dan perak tidak lagi dominan, sebagian peranan teknik sulaman tersebut telah tergantikan oleh teknik bordiran, hal ini dikarenakan selain cepat pengerjaannya juga harga lebih menenggang, dan kwalitas keindahannya masih tetap terjaga.

\section{KEPUSTAKAAN}

Asnan, Gusti, 2003. Kamus Sejarah Minangkabau. Padang: Pusat Pengkajian Islam dan Minangkabau.

Aswar, Sativa Sutan, 1999, Antakesuma Suji Dalam Adat Minangkabau, Djambatan, Jakarta.

Djelantik, A.A.M. 2004, Estetika Sebuah Pengantar, Bandung: MSPI

Feldman, Edmund Burke. (1967), Art as Image and Idea, Prentice-Hall Inc. Englewood Cliffs, New Jersey.

Moenir, 1984, Pelaminan, Museum Negeri Adhityawarman Sumatera Barat, Padang.

Moleong, Lexy J. 2009, Metodologi Penelitian Kualitatif edisi revisi, PT Remaja Rosdakarya, Bandung.

Mutia, Riza, dkk, 2000, Upacara Adat Perkawinan Di Padang Pariaman, BPP Permuseuman Suamtera Barat, Padang.
Navis, Ali Akabar, 1984, Alam Takambang Jadi Guru, Gratfitipres, Jakarta.

Raudha Thaib, Puti Reno, 2009, Palaminan Minangkabau, Bundo Kanduang Sumatera Barat (Padang).

Sony Kartika, Dharsono. 2007, Kritik Seni, Bandung: Rekayasa Sains. 